\title{
Factors Affecting Job Opportunities for University Graduates in China---the Evidence from University Graduates in Beijing
}

\author{
Kong Jun (Corresponding author) \\ School of Economics and Management, Northwest University \\ No.1 Xuefu Avenue, Guodu Educational and Industrial Zone \\ Chang'an District, Xi'an, 710127, Shaanxi, China \\ Tel: +86-29-87885476_E-mail: junkong555@hotmail.com \\ Jiang Fan \\ Department of Economics and Geography, Texas Tech University \\ 6302 Elgin Avenue, Indian Creek Apt 46, 79413 Lubbock TX, USA \\ Tel: +1-806-789-7857 E-mail: sherman_421@yahoo.com.cn
}

Received: December 29, $2010 \quad$ Accepted: January 15, $2011 \quad$ doi:10.5430/rwe.v2n1p24

\begin{abstract}
The problem of unemployed university graduates has become serious in China since the expansion of the higher education system in 1999, leading to an unemployment spell. Of China's 5.6 million university graduates in 2008 , 1.7 million are reported to have been unable to find jobs. In this paper, the factors that determine whether a graduate finds a job in China have been studied. A duration model for this study indicates that the graduates find jobs faster if they come from colleges with higher reputation. In addition, study shows graduates with engineering and business degrees find jobs more easily, next is major of arts and social science. The graduates with law and science degrees find jobs more difficult. Other majors have no significant effects on job finding. Finally, female graduates find jobs more easily than male graduates particularly before the final graduation date and 1-2 months after graduation.
\end{abstract}

Keywords: Unemployment Spell, Job Search, Factors

\section{Introduction}

Education, employment and marriage are the three pillars of Chinese traditional culture and finding desirable jobs is crucial for young graduates to be successful in their future career. There are many factors affecting job search, including individual ones or those that have something to do with the colleges attended. This paper divides the factors affecting the young Chinese graduates into two separate categories. One category studies the effect of the reputation of college and the second category delves into the individual factors that include gender and the majors studied at college. For the purpose of this paper, a duration model including parametric survival approaches, semi-parametric survival approaches, and nonparametric survival approaches is used to analyze the length of the unemployment spell. Moreover, these approaches reveal these factors' marginal effects based on the comparison variables that defined in the two categories. The marginal effect analysis shows that reputation of college, gender and major have significant effects on job search except for some majors such as agriculture, medicine and manufacturing. The further test reveals these factors' marginal effects are significantly different except for majors of engineering and business.

There are different conclusions about these factors affecting job search in different countries. One paper about the graduates in England suggests that the reputation of college has a significant effect on the graduates' job search (Bradley \& Nguyen, 2004, pp 484-521). As far as gender is concerned, Bratberg and Nilsen present a logistic model that shows female graduates in Norway entering the labor market ahead of males (Bratberg \& Nilsen, 1998, pp.1-29). On the contrary, a similar study in China suggests that reputation has a slight effect on job search using logistic model (Zhou, 2003, pp.12-20). A similar study in China suggests a slight effect on job search using logistic model (Zhou, 2003, pp.12-20). Meanwhile, graduates of certain majors such as law, computer and English education found it more difficult to secure jobs in China in 2008 (www.mycos.com.cn). Furthermore, Zhou and Min et al. indicate a different trend in China with the female graduates finding it more difficult to secure job (Zhou, 2003, pp.12-20; Min et al., 2006, 
pp.13-26).

In this paper a duration model, which focuses on survival analysis has been applied to the factors that affect new graduate job search. Zhou and Min et al. have studied graduates' job search in China (Zhou, 2003, pp.12-20; Min et al., 2006. pp.13-26). However, in their models, the data is based on questionnaires randomly distributed among college graduates from 30 universities in 6 provinces and 34 universities in 16 provinces of 31 provinces with 2,119 universities and colleges totally in China. Their researches cannot predict precise national and regional trends. Therefore, this paper adopts a dataset which covers all colleges in Beijing area in order to acquire an accurate regional trend. Finally, this paper also demonstrates the marginal effects of each factor disregarded in their studies.

This research finds graduates from colleges with good reputation to have better job opportunities with female graduates entering the labor market first. Concurrently, the majors of engineering, business, arts and social science, law, and science have significant effects on job search in duration model. The graduates from majors of engineering and business find jobs most easily, next is major of arts and social science. The graduates from majors of law and science find jobs most difficult. Other majors have no significant effects on job search. In addition, the female graduates are more successful in finding jobs than male graduates. Therefore, the main result is that the female graduates from reputed colleges with degrees of engineering and business are given the first preference.

In the section below the existing literature on the topic is reviewed and in section 3 the dataset is introdced. Sections 4 and 5 are data descriptions and summary statistics respectively. Section 6 presents the empirical econometric model and estimation. The final section is the conclusion.

\section{Literature Review}

The following literature reviews that affect graduates' job search involving reputation of school, major, gender, and other relative factors. Although other relative factors such as college achievement, internship and education level are not key points in this paper due to insufficient observations. The literature of these factors is still reviewed to understand the research comprehensively. In addition, some of researches are introduced from other countries to indicate the different outcomes.

Bradley and Nguyen (2004, pp.484-521) point out that the index of school quality has a much larger effect than academic performance on the transition of school-to-labor in England. However, Zhou (2003, pp.12-20) uses a survey that covers 30 colleges in 6 provinces, including available college samples of 18,722 graduates in China and finds that the reputation and quality of the colleges have only a small effect on whether the graduates find jobs. The contribution of coefficient is $1.4 \%$ which means that a reputation increase of 1 will cause an increase of $1.4 \%$ on the probability of finding a job if it is changed from the ordinary colleges to the reputed universities.

Second, for major, the data from the online consulting firm MyCos demonstrates that it was very difficult for the graduates with bachelor degrees in law, computer science and English education to find jobs in China in 2008 (www.mycos.com.cn). Furthermore, for gender, Bratberg and Nilsen (1998, pp.1-29) use Norwegian data and find that females have lower reservation wages when entering the labor market (shorter search time and lower wages). Bradley and Nguyen (2004, pp.484-521) point out the males from high quality schools are less likely to enter the labor market and get jobs compared to the females in England. They are more likely to stay unemployed. Conversely, Zhou (2003, pp.12-20) reveals that male graduates find jobs more easily than female graduates in China. Min et al. (2006, pp.13-26) also show the percentage of male graduates signing job contracts is $77.1 \%$ as opposed to the female's figure of $71.2 \%$. Ghazala (2006, pp.1-38) finds that gender gaps in unemployment rates have risen in the past 20 years in many European countries. Another set of data from the 2008 Korean Statistical Survey shows that, by gender, the total average employment rate of female graduates was $2.6 \%$ lower than the rate for males in Korea. The gap grows to $7.7 \%$ when counting full-time employment only (www.korea.net).

In the United States, Sum, Harrington \& Simpson (1983) attribute the higher unemployment rate to be due to inadequate educational attainment. Norman (1984) reveals that the American high school graduates in the late 1960's were 30\% more likely to be employed than dropouts. Wolpin (1987, pp.801-17) reveals an opposite trend in United States and argue that higher reservation wages lead to a longer duration of unemployment. This implies that the graduates may have a longer unemployment spell when they are from better colleges or if they own higher education levels because they have a higher expected value of wages. Stern (1989, pp.348-369) shows that the college graduates accepted larger mean offers than that of dropouts during the same period.

Eckstein and Wolpin (1995, pp.263-86) find that differences in unemployment durations by race and schooling in United States are primarily due to differential rates at which job offers are accepted rather than to differential job offer probabilities. Bjorklund and Eriksson (1996, pp.96-116) study the case of the Nordic countries and indicate a lower 
unemployment rate for workers with high education than for those with low education. Bratberg and Nilsen (1998, pp.1-29) demonstrate that education is important for getting a job quickly, and that it also has a positive wage effect in Norway. In addition, individuals with a higher level of education have the longer first job duration. They also find that doing apprentices (internships) seems to shorten job search time relative to individuals at the same educational level who opt out of it.

Zhou (2003, pp.12-20) finds that it was easier for graduates with master degree to find job than for those with bachelor and doctor degree in China. Fang et al. (2004, pp.189-204) finds that MIS (Master of Information System) students in America have adopted aggressive approaches such as double majors to secure employment. This shows more education and more training to enhance the success of employment. Spitz-Oener (2006, pp.235-270) shows the proportion of the workforce holding a university degree increased from about $8 \%$ in 1979 to more than $16 \%$ in 1999 , whereas there is a substantial decline in the proportion of employees without formal education in Germany. This indicates that more and more enterprises require higher education levels. In Korea, the employment rates of students from junior colleges, universities and graduate schools marked $85.6 \%, 68.9 \%$ and $81.6 \%$ respectively in 2008 (www.korea.net).

Finally, regarding the effect of graduates' college achievement on job finding, Jensen and Westergard-Nielsen (1987, pp.461-72) use the data collected in Denmark to indicate that the average grades have positive effect on the job search. Conversely having had too many part-time jobs has negative effects. Bertschy, Cattaneo \& Wolter (2008, pp.1-31) analyze PISA 2000 data from Switzerland and show that the compulsory school achievements measured by individual PISA results have no direct effect on the labor market transition. However, the graduates with higher PISA scores seem to demand more vocational training and eventually have better job prospects.

The contribution of this paper lies in that a duration model focuses on survival analysis has been applied to the factors that affect new graduate job search. Previous researches often use logistic model to analyze job search from Bratberg \& Nilsen (1998, pp.1-29), Zhou (2003, pp.12-20) and Min et al. (2006, 13-26). Secondly, this paper adopts a dataset which covers all colleges in Beijing area in order to acquire an accurate regional trend that Zhou (2003, pp.12-20) and Min et al. (2006, pp.13-26) cannot predict. Finally, this paper also demonstrates the marginal effects of each factor disregarded in their studies.

\section{Introduction of Dataset}

This dataset is supplied by MyCos, a private company maintaining educational database in China. The company covers 27 provinces and 4 special regions which are the municipalities directly under the jurisdiction of the central government and cover 2113 universities. The dataset used in this study covers the universities and vocational colleges within the special region of Beijing and includes all majors offered in this region. The "Chinese College Graduates Employment and Skills Annual Survey," posted by MyCos is designed to provide information about college graduates' job search, employment status, basic work skills and occupational skills. It builds up the national college graduates follow-up database which is posted on the China Survey Center website. The China Survey Center was set up by Beijing University and the University of Michigan in November, 2008. The survey population includes universities, four years regular or three years vocational colleges, half a year after graduation in 2006 and 2007. This paper uses the dataset from the Beijing area in 2007 because Beijing owns the most developed education and labor market.

\section{Data Description}

The dataset provides information about college graduates' job search, employment status, basic work skills, and occupational skills in 2007. This paper only focuses on the variables that include the reputation of college, major, and gender. The other variables such as the cost of job search, internship and search time before graduation have been disregarded due to inadequate observations with numbers of 5,239, 5,581 and 5,545, which occupy $63.80 \%, 67.96 \%$ and $67.52 \%$ of 8,212 which are total observations for regression respectively. The original dataset needs to be specialized to fit with the requirements of the Duration Model. Hence, the dataset has been left the observations of 8,212 for regression in Table 2. Furthermore, major fields can be combined into 8 categories from 28 types in Table 1, and the reputation of college, majors and gender are all dummy variables.

The Different categories of colleges are used for the effect of reputation. This paper classifies categories of colleges into high reputation four-year universities, ordinary four-year colleges and three-year colleges.

Secondly, Table 1 shows that 8 main types of majors cover arts and social science, science, engineering, law, medicine, agriculture, business and manufacturing. The major of arts and social science includes philosophy, economics, education, literature, history, tourism, human services, culture and education, and arts and communication. The major of science includes natural science, meteorology, and computer science. The major of law includes law, public security, and jurisprudence. The major of engineering includes engineering, transportation, civil engineering, and water conservancy. 
The major of agriculture includes agronomy, forestry and fishery. The major of medicine includes medical science, biochemistry and medicine, and hygiene. The major of business includes management, and finance. The manufacturing includes textile, garment and food industries.

\section{Summary Statistics}

Table 2 provides descriptive statistics on college type, major, gender, and average duration of unemployment. Regarding college type, high reputation four year university's percentage of employment reaches $92.62 \%$ of total number of their graduates. The employed percentages of other two types of college are $93.60 \%$ and $89.46 \%$ respectively. Secondly, the major fields had to be compressed into 8 categories in order to visualize and regress simply. Most graduates with employment are from the majors of arts and social science, engineering and business. Their numbers are 2,034, 2,206 and 2,052 respectively of total employment at 7,619. For this reason there are many students graduating from these majors each year. Furthermore, the number of employed female graduates reaches 3,899 which are slightly more than the number of male graduates at 3,720. The total unemployment figure for females is 284 versus the figure for males at 309.

In addition, the graduates from high reputation four-year universities and ordinary four-year colleges have the shorter average duration of unemployment, which are 7.22 and 7.10 months, compared to the number of three-year colleges, which is 7.56 months. From the view of major classification, the graduates from majors of manufacturing and business own the shorter average duration of unemployment, which are 6.64 and 6.97 months, compared to the figure from majors of law and engineering, which are 7.31 and 7.33 months. Meanwhile, the average durations of unemployment from arts and social science, science, agriculture and medicine are in middle place. Moreover, female graduates have a significant shorter average duration of unemployment, which is 7.14 months, compared to male's 7.26 months. Average duration of unemployment reflects average job search time. It does not reveal marginal hazard rate of unemployment.

Furthermore, Table 3 shows the data for the status of the employed, the unemployed and the non-employed. Of these, $92.78 \%$ of graduates find jobs covering all types of college, and $4.02 \%$ are graduates still looking for jobs. Others are preparing for graduate school tests and for overseas study and have no immediate plans to search jobs. Their percentage reaches $3.2 \%$. Table 4 shows the numbers and percentage of the employed, and the unemployed and non-employed during the discrete unemployment spell. Most cases for employment occur during the 6, 7 and 8 months of the spell. The base time of duration model is at 6 months before graduation in this research. There are cases in dataset of some students who have entered the labor market before graduation. According to MyCos's standard for full-time job in the survey, if students work for 4 hours each day, they are fully employed. In China, the common time for a bachelor's degree is 4 years and for an associate bachelor's degree is 3 years. Students complete all courses in first three years in four-year colleges and first two years in three-year colleges, and go through internship for one semester and prepare thesis in the last semester. Hence, the time is flexible for them in the final year. Some students find jobs and work even if they have not graduated. This phenomenon is common in China now although rare 20 years ago.

In addition, Table 4 shows the numbers and percentage of unemployment type. 55.65\% of unemployed graduates are still searching jobs. Others are preparing for graduate school test, and for oversea study and no plan for further study or nom plan to search jobs temporarily. Table 5 shows the numbers and percentage of employment and unemployment during the discrete unemployment spell. The most cases take place at the duration of 6,7 and 8 month. The base time of duration model occurs at 6 months before graduation in this research. There are cases in dataset that some students have entered the labor market before graduation. According to MyCos's standard of full job in the survey, if students work for 4 hours on job each day, they are fully employed. In China, the common spell of bachelor is 4 years. Students complete all courses in first three year, and go through internship for one semester and prepare thesis in last semester. Hence, the time is flexible for them in last year. Some students find jobs and work even if they have not graduated. This phenomenon is common in China now although rare 20 years ago.

\section{Empirical Model and Estimation}

\subsection{The Empirical Model}

A duration model is used in this paper to analyze the factors that affect the length of the unemployment. The duration model has the parametric survival approaches, the semi-parametric survival approaches, and the nonparametric survival approaches. First, the parametric survival model (PSM) requires the unemployment spell with a standard distribution such as normal, log normal, exponential, Weibull, and logistic distribution etc. The PSM with a standard distribution is:

$$
\operatorname{Ln}(t)=\alpha+\beta_{i} X_{i}+\sigma \varepsilon_{i}
$$

The unemployment spell, namely, $t$ starts from 6 months before graduation. Some students have found jobs and worked for 5, 4, 3, 2 and 1 months before graduation. The earliest time that graduates find jobs is 5 months before 
graduation. The figure of unemployment spell may be negative if graduation time is set as base time. Statistical software cannot permit negative number. Hence, this paper set time 6 months before graduation as base time in order to run it in software. From Table 3.4, the maximum of unemployment spell is 16 months suggesting that graduates find jobs within 10 months after graduation and the minimum is 1 month suggesting that the graduates find jobs at 5 months before graduation because some students actually start to be employed prior to completing school. Most graduates find jobs within 1 and 2 months after graduation or immediately after graduation with total percentage of $59 \%$.

Therefore, the duration time can be recalculated as in the following equation:

$$
t=12 \text { months }+ \text { answermont } h-(\text { jobtime })
$$

The survey takes place on Dec. 2007, which is 6 months after graduation on June, 2007. And the base time is 6 months before graduation. Thus the survey time occurs after 12 months from the base time. The answer month means the response month after the graduates complete the surveys. It is commonly in Feb. or March, 2008. Meanwhile, the job time stands for the time that the graduates have worked for the current employer. In addition, $\alpha$ is constant and $\beta_{i}$ are coefficients of explanatory variables that affect $t . \varepsilon_{i}$ is a random variable with a standard distribution. $\sigma$ is the coefficient of variation and $X_{i}$ stands for explanatory variables including college reputation, major and gender.

Secondly, the semi-parametric survival model (SPSM) and nonparametric survival model (NSM) are used to verify the result of the PSM because SPSM and NSM do not require a theoretical distribution of $t$. SPSM refers to the proportional hazard model (Cox regression) and NSM refers to the Kaplan-Meier survival function. The Cox regression is defined as following equation:

$$
\begin{gathered}
h(t)=h_{0}(t) \exp \left(\beta_{i} X_{i}+\varepsilon_{i}\right) \\
\operatorname{Ln}[h(t)]=\operatorname{Ln}\left[h_{0}(t)\right]+\beta_{i} X_{i}+\varepsilon_{i}
\end{gathered}
$$

$h(t)$ is the hazard rate for failure, $h_{0}(t)$ is base hazard rate. The Kaplan-Meier survival function is:

$$
S(t)=\prod_{j=t_{0}}^{t}\left\{\left(n_{j}-d_{j}\right) / n_{j}\right\}
$$

$S(t)$ is the survival function at time $t, n_{j}$ is a total observations of graduates at time $j, d_{j}$ is the number of failures, namely, the employment numbers at time $j$. The Kaplan-Meier survival function is mainly used for an analysis of survival probability by visual diagram. This model's advantage lies in that it does not require a standard distribution when it process data.

Regarding the explanatory variables, this paper uses dummy variables for reputation: the high reputation four-year university (best university registered by Ministry of Education, China), the ordinary four-year college and the three-year college. The ordinary four-year college and three-year college are taken as comparison variables respectively in the regression. Majors cover arts and social science, law, science, engineering, agriculture, medicine, business and manufacturing as dummy variables. Arts and social science, engineering and business are regarded as comparison variables. Gender is a dummy variable and male is comparison variable. This paper does not use education level as explanatory variable because the bachelors occupy $99.28 \%$ of total graduates. Internship and the length of the unemployment also cannot be used for explanatory variables due to inadequate observations in dataset.

\subsection{Estimation Results}

The parametric survival model is used to analyze the factors that affect the duration of unemployment for the graduates. Figure 1 indicates that $\log$ of the Weibull hazard is a linear function of log unemployment time. Hence, the Weibull regression can be used to analyze what factors affecting unemployment spell.

Furthermore, the Cox proportional hazard model is used to analyze hazard rate to verify the result of Weibull regression. This model does not require a standard distribution of unemployment spell. Through test, hazard rates of reputation of universities, major, and gender are not proportional in the Cox model. The result is consistent with that of the Weibull regression. In addition, The Kaplan-Meier Function, which does not need a standard distribution, it is used to analyze the unemployment spells or hazard rates of reputation of universities, major, and gender. This paper uses the diagram of this function that can show clear and true hazard rates of reputation of universities, major, and gender in order to verify the results from the Weibull regression and the Cox proportional model. Diagram 2, 3, and 4 of the Kaplan-Meier Function indicate hazard rates of reputation of university, major, and gender are not proportional respectively. It indicates that graduates from different types of college, or different majors, or different genders have different hazard rates. The result from Cox model supports the results from Weibull regression and Cox model.

The outcome of Weibull distribution from the parametric survival model shows the reputation of college, some of majors 
except for agriculture, medicine, business and manufacturing, and gender to have a significant effect on unemployment spell at $1 \%$ or $5 \%$ level considering three-year colleges, engineering and male as base variables in Table 5. First, the higher reputation four-year universities will decrease the unemployment spell greatly. The hazard rate of high reputation four-year universities is 1.368 compared to 1 , which is number of three-year colleges. This reveals the graduates from these universities will find jobs faster than the graduates from three-year colleges. The marginal effect analysis in Table 6 indicates that the number for high reputation universities is about -1.03 based on three-year colleges, which means that the graduates' unemployment spell will decrease 103\% compared to that of three-year colleges. Meanwhile, the hazard rate of ordinary four-year colleges is 1.305 . This reveals the graduates from these universities will find jobs faster than the graduates from three-year colleges. The marginal effect analysis indicates that the number of four-year colleges is about -0.85 , which means that the graduates' unemployment spell will decrease $85 \%$ compared to that of three-year colleges.

Furthermore, test the hypothesis that hazard rate of high reputation four-year universities equal to that of ordinary four-year colleges, and finds that test with number of $6.29 \%$ cannot reject the equality hypothesis at the $5 \%$ level, but can at the $10 \%$ level. Therefore, regression for marginal effects is redone based on variable of ordinary four-year colleges. And finds that the marginal effect for high reputation four-year universities' hazard rate will decrease $15.33 \%$ compared to that of ordinary four-year colleges at $10 \%$ significant level although its average unemployment spell is longer than the latter, and hazard rate will increase $91.15 \%$ if graduates came from the three-year colleges at $1 \%$ significant level. This result indicates that graduates from high reputation four-year universities find jobs more easily than graduates from other colleges, and graduates from three-year colleges find jobs most difficult.

Secondly, the regression outcome for majors indicates that graduates will find jobs more easily if they come from majors of engineering and business, than the graduates from arts and social science, law and science at $1 \%$ significant level. The Table 3.5 indicates the hazard rates for arts and social science, law, and science are about $0.90,0.73$ and 0.79 respectively compared to 1 for engineering graduates. The marginal effects of hazard rate in Table 3.6 indicate that the unemployment spells will increase $34.26 \%, 108 \%$ and $78.70 \%$ respectively for graduates from arts and social science, law, and science, compared to graduates from engineering. If arts and social science is regarded as the comparison variable, the graduates' unemployment spells for law, and science will increase $70.79 \%$ and $42.53 \%$, on the contrary, that for engineering, and business will decrease $33.57 \%$ and $40.45 \%$. If business is the comparison variable, the graduates' unemployment spells for arts and social science, law and science will increase $41.49 \%, 116 \%$ and $86.42 \%$ respectively. If agriculture is the comparison variable, the graduates' unemployment spells for law, and science will increase $100 \%$ and $70.90 \%$. However, its spell has no significant difference with arts and social science, engineering, and business. There are also no significant differences about unemployment spell between engineering and business, and between law and science by test. Therefore, the graduates from majors of engineering and business or agriculture find jobs most easily, next is major of arts and social science or agriculture. The graduates from majors of law and science find jobs most difficult. Other majors have no significant effects on hazard rates.

Moreover, the female graduates find jobs faster because their hazard rate is 1.05 more than that of the male graduates. Their unemployment time will decrease $15.91 \%$. In addition, the parameter of $\mathrm{p}$ is greater than 1 . It indicates that the possibility of finding a job for the graduates becomes larger with time, namely, "accelerated failure".

From the analysis of the Cox proportional hazard model in Table 7, the outcome is consistent with the outcome using the parametric survival model. The hazard rates for high reputation universities and ordinary four-year colleges are 1.20 and 1.22 respectively compared to 1 , which is the figure for the three-year colleges. This outcome indicates faster job finds for the graduates from high reputation four-year universities and ordinary four-year colleges. The hazard rate for engineering graduates is greater than that of arts and social science, law, science at 5\% significant level. There are no different effects between engineering and business as well as between law and science. The female graduates' hazard rate is more than that of male graduates, and shows them finding jobs faster.

In addition, proportionality of hazard rate is tested in Table 8, Table 9, and Table 10. To do this, the paper generates the time dependent covariates by creating interactions of the factors and a function of unemployment spell that included in the Cox model. Those factors are not proportional if any of the time dependent covariates are significant.

From Table 8, the result indicates that hazard rates of reputation of university are not proportional because high reputation of university of the unemployment-time dependent covariate is significant at 1\% level. From Table 9, arts and social science, law, and science of the unemployment-time dependent covariates are significant at $1 \%$ level. This shows that hazard rates of majors are not proportional. Table 10 also shows same result that hazard rates of gender are not proportional. 
Furthermore, Figure 2 reveals the hazard rates for colleges with different reputations to be different from Kaplan-Meier Function. Horizontal axis, namely analysis time stands for unemployment spell, and vertical axis for hazard rate. If hazard rates are proportional to the baseline hazard rate, the lines of hazard rate should be parallel together. Obviously, their hazard rates are not proportional to the baseline hazard rate, namely, their hazard rates are different in each discrete unemployment spell. This implies that some graduates find jobs more easily and some of them find jobs more difficult when they come from different types of college. Meanwhile, it is indicated that the hazard rates for high reputation four-year university graduates are lower than other colleges 0-4 months prior to graduation. However, the high reputation four-year university graduates are more successful in finding jobs after graduation.

In addition, Figure 3 indicates that the graduates with engineering degrees find jobs more slowly than the graduates from other majors before graduation, this is the reason that engineering graduates have a longer average unemployment spell, but they find jobs faster after graduation particularly. Business graduates always find jobs faster not only before graduation but also after graduation. Engineering graduates find jobs more slowly than business graduates before graduation and faster than them after graduation. The graduation with arts and social science find jobs slower than that from engineering and business, but they find jobs faster than that from law and science. Between law and science, their hazard rate lines kink together. It is difficult to distinguish which graduates find jobs more easily. This results support the conclusion from Weibull Regression. Their hazard rates are also not proportional to the baseline hazard rate.

Finally, Figure 4 also shows that the hazard rates for different genders are not proportional to the baseline hazard rate. Female graduates search jobs actively and find jobs faster before graduation. Male graduates catch up with female graduates in employment rate after graduation.

\section{Conclusion}

This paper tries to outline the factors affecting graduate unemployment spell. The research shows that graduates find jobs faster if they come from the high reputation four-year universities, because they have higher reputations compared to the four-year and three-year colleges. The high reputation four-year university graduates are more confident to their job search and they are more successful after graduation. Other graduates may start to search jobs earlier and some find employment before graduation. Regarding major, the graduates with engineering and business or agriculture degrees find jobs most easily, next is major of arts and social science or agriculture. The graduates with law and science degrees find jobs most difficult. Other majors have no significant effects on hazard rates. In addition, the female graduates are more successful in finding jobs before graduation and 1-2 months after graduation.

It is therefore concluded that firstly, female graduates begin to work earlier. This result is different from previous researches that male graduates find jobs more successfully in China. Secondly, graduates from colleges with better reputation are more successful in their job search particularly after graduation. This outcome is different from Zhou's studies that indicate reputation only has slight effect on job search in China, but is same as previous outcomes studied from other countries. Finally, engineering and business graduates find jobs more easily, and law and science graduates find jobs more difficult. This is also similar to previous researches that mention law graduates find job more difficult in China.

\section{References}

Alexandra Spitz-Oener. (2006). Technical Change, Job Tasks, and Rising Educational Demands: Looking outside the Wage Structure, Journal of Labor Economics, 24 (2), 235-270. doi:10.1086/499972, http://dx.doi.org/10.1086/499972

Bertschy, Kathrin \& Cattaneo, Alejandra \& Wolter, Stefan. (2008). What Happened to the PISA 2000 Participants Five Years Later? IZA Discussion Papers 3323, (pp.1-31), Institute for the Study of Labor (IZA)

Bjorklund, Anders and Eriksson, Tor. (1996). Unemployment in the Nordic Countries, In the Nordic Labour Markets in the 1990's, (pp.96-116), edited by Eskil Wadensjo, Amsterdam: Elsevier, 1996.

Bradley, S. and A. N. Nguyen. (2004). The School-to-Work Transition, International Handbook of Education Economics, Cheltenham, (pp.484-521): Edward Elgar (Eds G. Johnes and J. Johnes).

Bratberg, E. and O. A. Nilsen. (1998). Transitions from School to Work: Search Time and Job Duration, IZA, DP, 27, $1-29$.

Eckstein Z, Wolpin KI. (1995). Duration to First Job and the Return to Schooling: Estimates from a Search-Matching Model, Review of Economic Studies 62 (2), 263-86. doi:10.2307/2297805, http://dx.doi.org/10.2307/2297805

Fang Xiang, Lee Sooun, Lee Ted and Huang. (2004). Critical Factors Affecting Job Offers for New MIS Graduates, Journal of Information System Education, 15, (2), 189-204. 
Ghazala Azmat, Maia Guell \& Alan Manning. (2006). Gender Gaps in Unemployment Rates in OECD Countries, Journal of Labor Economics, 24, (1), 1-38.

Jensen P, Westergard-Nielsen NC. (1987). A Search Model Applied to the Transition from Education to Work, Review of Economic Studies, 54, (3), 461-72. doi:10.2307/2297569, http://dx.doi.org/10.2307/2297569

Min Weifang, Ding Xiaohao, Wen Dongmao and Yue Dongchang. (2006). The Survey on the College Graduates in 2005, Guan Ming Observation, 3, 13-26.

Minstry of education. (2008). Korea Labor Market for New Graduates, URL http://www.korea.net/news/newsnewsView.asp.

Mycos Company. (2009). Chinese College Graduates Employment and Skills Yearly Survey, URL http://www.mycos.cn/Downs/list.actions.

Norman Freeberg. (1984). Factors Affecting Job Search Behavior and Employment Outcome for Youth, Final Technical Report, Educational Testing Service, Princeton, N.J.

Steven Stern. (1989). Estimating a Simultaneous Search Model, Journal of Labor Economics, 7 (3), $348-369$. doi:10.1086/298212, http://dx.doi.org/10.1086/298212

Sum, Harrington \& Simpson. (1983). Educational Attainment, Academic Ability, and the Employability and Earnings of Young Persons: Implications for the Planning and Design of JTPA Youth Programs, Boston, MA: Northeastern University, Center for labor Market Studies.

Wolpin KI. (1987). Estimating a Structural Search Model: The Transition from School to Work, Econometrica 55 (4), 801-17. doi:10.2307/1911030, http://dx.doi.org/10.2307/1911030

Zhou, Jun Bo. (2003). A Study on Graduates' Costs in Job Hunting, Economics of Education Research (Beida), 1(1), 12-20.

Table 1. Major Field Classifications

\begin{tabular}{|c|r|}
\hline Major Name & \\
\hline $\begin{array}{c}\text { Arts and Social } \\
\text { Science }\end{array}$ & $\begin{array}{r}\text { philosophy, economics, education, literature, history, tourism, human services, } \\
\text { culture and education, and arts and communication }\end{array}$ \\
\hline Law & law, public security, and jurisprudence \\
\hline Science & natural science, meteorology, and computer science \\
\hline Engineering & engineering, transportation, civil engineering, and water conservancy \\
\hline Agriculture & agronomy, forestry and fishery \\
\hline Medicine & medical science, biochemistry and medicine, and hygiene \\
\hline Business & Management, and finance \\
\hline Manufacturing & textile, garment and food industries \\
\hline
\end{tabular}


Table 2. Numbers of Observations and Average Duration of Unemployment

\begin{tabular}{|c|c|c|c|c|}
\hline College Type & $\begin{array}{c}\text { Numbers of } \\
\text { the Employed }\end{array}$ & $\begin{array}{c}\text { Numbers of the } \\
\text { Unemployed and } \\
\text { Non-employed }\end{array}$ & Total & $\begin{array}{c}\text { Average } \\
\text { Duration }\end{array}$ \\
\hline $\begin{array}{c}\text { High Reputation } \\
\text { Four-year University }\end{array}$ & 4,406 & 351 & 4,757 & $7.22(.036)$ \\
\hline $\begin{array}{c}\text { Ordinary Four-year } \\
\text { College }\end{array}$ & 2,763 & 189 & 2,952 & $7.10(.058)$ \\
\hline Three-year College & 450 & 53 & 503 & $7.56(.152)$ \\
\hline Total & 7,619 & 593 & 8,212 & $7.20(.031)$ \\
\hline Major Field & 2,034 & 154 & 2,188 & $7.25(.064)$ \\
\hline $\begin{array}{c}\text { Arts and Social } \\
\text { Science }\end{array}$ & 562 & 81 & 643 & $7.31(.119)$ \\
\hline Law & 586 & 82 & 668 & $7.23(.107)$ \\
\hline Science & 2,206 & 130 & 2,336 & $7.33(.052)$ \\
\hline Engineering & 93 & 7 & 100 & $7(.266)$ \\
\hline Agriculture & 72 & 8 & 80 & $7.19(.284)$ \\
\hline Medicine & 2,052 & 130 & 2,182 & $6.97(.062)$ \\
\hline Business & 14 & 1 & 15 & $6.64(1.161)$ \\
\hline Manufacturing & 7,619 & 593 & 8,212 & $7.20(.031)$ \\
\hline Total & 3,899 & 284 & 4,183 & $7.14(.045)$ \\
\hline Gender & 3,720 & 309 & 4,029 & $7.26(.042)$ \\
\hline Female Graduates & 7,619 & 593 & 8,212 & $7.20(.031)$ \\
\hline Male Graduates & & & & \\
\hline Total & & & & \\
\hline
\end{tabular}

8,212 is the number of regression in duration model. The figures in parentheses refer to standard error.

Table 3. Numbers and Percentage of Employment, Unemployment, and Non-employment

\begin{tabular}{|c|c|c|}
\hline Type & Observations & Percentage (\%) \\
\hline Employment & 7,619 & 92.78 \\
\hline Unemployed, still looking for a job & 330 & 4.02 \\
\hline Non-employed, full time preparing for graduate school test & 111 & 1.35 \\
\hline Non-employed, preparing for oversea study & 49 & 0.60 \\
\hline Non-employed, no job search and no plan for graduate study & 103 & 1.25 \\
\hline Total & 8,212 & $100 \%$ \\
\hline
\end{tabular}


Table 4. Numbers and Percentage of Employment, Unemployment, and Non-employment in Unemployment Spell

\begin{tabular}{|c|c|c|c|}
\hline $\begin{array}{c}\text { Unemployment Spell } \\
\text { (Month) }\end{array}$ & Employment & $\begin{array}{c}\text { Unemployment and } \\
\text { Non-employment }\end{array}$ & $\begin{array}{c}\text { Percentage (\%) of } \\
\text { Employment }\end{array}$ \\
\hline 0 & 0 & 8,212 & 0 \\
\hline 1 & 171 & 8,041 & 2.08 \\
\hline 2 & 277 & 7,764 & 3.37 \\
\hline 3 & 303 & 7,461 & 3.69 \\
\hline 4 & 298 & 7,163 & 3.63 \\
\hline 5 & 360 & 6.803 & 4.38 \\
\hline 6 & 1,223 & 5,580 & 14.89 \\
\hline 7 & 1,950 & 3,630 & 23.75 \\
\hline 8 & 1,323 & 2,307 & 16.11 \\
\hline 9 & 553 & 1,754 & 6.73 \\
\hline 10 & 317 & 1,437 & 3.86 \\
\hline 11 & 266 & 1,171 & 3.24 \\
\hline 12 & 223 & 948 & 2.72 \\
\hline 13 & 144 & 804 & 1.75 \\
\hline 14 & 146 & 658 & 1.78 \\
\hline 15 & 58 & 600 & 0.71 \\
\hline 16 & 7 & 593 & 0.08 \\
\hline Total & 7,619 & & 92.78 \\
\hline
\end{tabular}

Table 5. Outcome of Weibull Regression

\begin{tabular}{|l|c|c|c|c|c|c|}
\hline Variables of Unemployment Spell & Haz. Ratio & Std. Err. & $\mathrm{z}$ & $\mathrm{P}>|\mathrm{z}|$ & \multicolumn{2}{|c|}{$95 \%$ Conf. Interval } \\
\hline High Reputation Four-year University & 1.368003 & .0685745 & 6.25 & 0.000 & 1.239991 & 1.50923 \\
\hline Ordinary Four-year College & 1.305144 & .0673645 & 5.16 & 0.000 & 1.179571 & 1.444086 \\
\hline Three-year College(omitted)* & & & & & & \\
\hline Arts and Social Science & .9010508 & .0292167 & -3.21 & 0.001 & .8455688 & .9601733 \\
\hline Law & .7308101 & .035103 & -6.53 & 0.000 & .6651488 & .8029533 \\
\hline Science & .7929949 & .0369899 & -4.97 & 0.000 & .7237113 & .8689113 \\
\hline Engineering (omitted)* & & & & & & \\
\hline Agriculture & .9780878 & .1037849 & -0.21 & 0.835 & .7944322 & 1.204201 \\
\hline Medicine & .8744041 & .1049172 & -1.12 & 0.263 & .6911606 & 1.10623 \\
\hline Business & 1.021947 & .0324281 & 0.68 & 0.494 & .9603253 & 1.087523 \\
\hline Manufacturing & 1.026626 & .2763022 & 0.10 & 0.922 & .6057917 & 1.739808 \\
\hline Female Graduates & 1.050097 & .0253763 & 2.02 & 0.043 & 1.001519 & 1.10103 \\
\hline Male Graduates(omitted)* & & & & & & \\
\hline $\ln \_\mathrm{p}$ & .8445466 & .008997 & 93.87 & 0.000 & .8269128 & .8621803 \\
\hline $\mathrm{P}$ & 2.326922 & .0209353 & & & 2.28625 & 2.368319 \\
\hline $1 / \mathrm{p}$ & .4297522 & .0038665 & & & .4222405 & .4373975 \\
\hline
\end{tabular}

*refers to comparison variables are Three-Year College, Engineering and Male. 


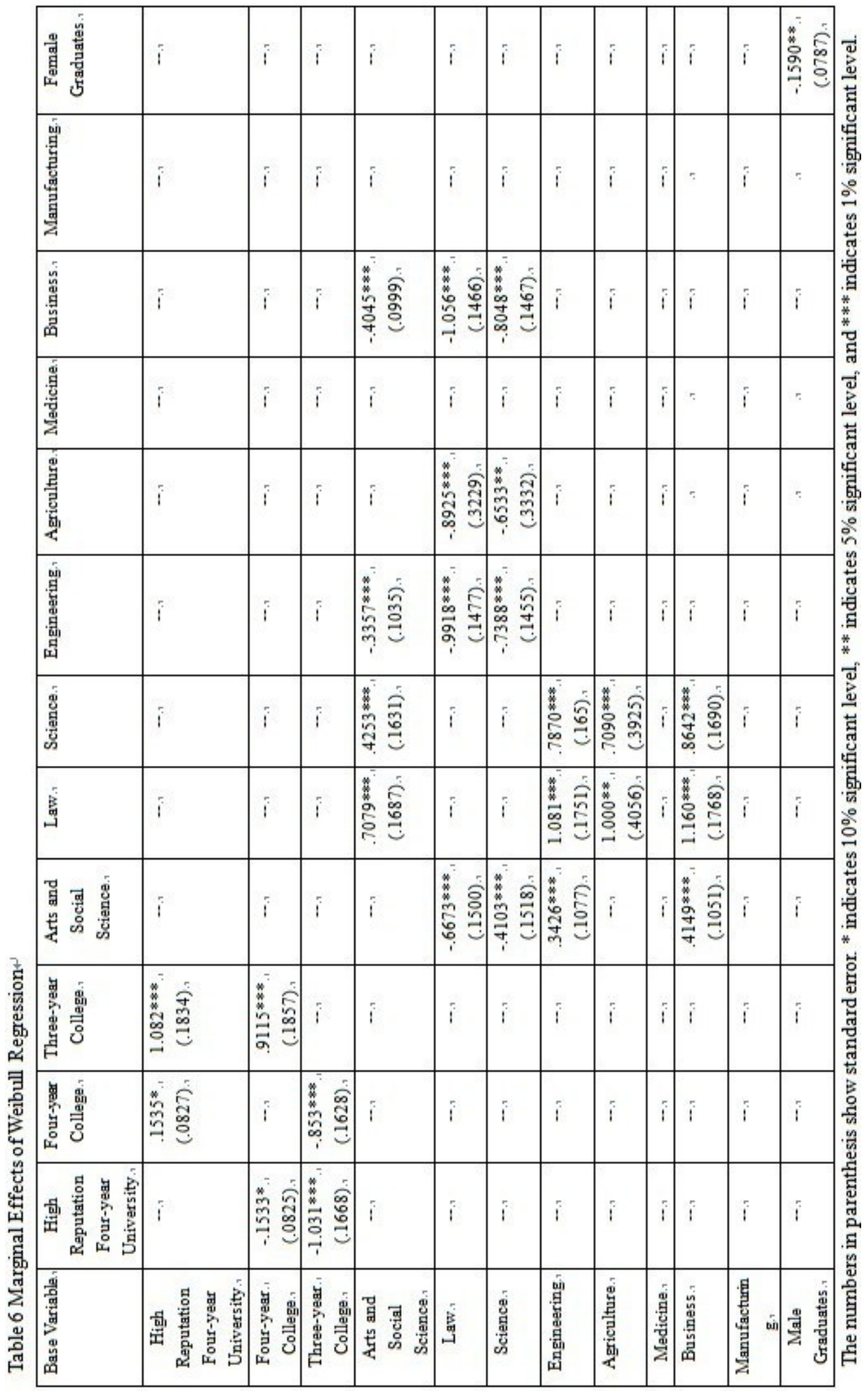


Table 7. Outcome of Regression by Cox Proportional Hazard Model

\begin{tabular}{|c|c|c|c|c|c|c|}
\hline $\begin{array}{c}\text { Variables of } \\
\text { Unemployment Spell }\end{array}$ & Haz. Ratio & Std. Err & $\mathrm{z}$ & $\mathrm{P}>|\mathrm{z}|$ & \multicolumn{2}{|c|}{$95 \%$ Conf. Interval } \\
\hline $\begin{array}{c}\text { High Reputation } \\
\text { Four-year University }\end{array}$ & 1.204392 & .0603534 & 3.71 & 0.000 & 1.091725 & 1.328687 \\
\hline $\begin{array}{c}\text { Ordinary Four-year } \\
\text { College }\end{array}$ & 1.219441 & .0628832 & 3.85 & 0.000 & 1.102216 & 1.349134 \\
\hline $\begin{array}{c}\text { Three-year } \\
\text { College(omitted) }\end{array}$ & & & & & & \\
\hline Arts and Social Science & .9408672 & .0304974 & -1.88 & 0.060 & .8829525 & 1.002581 \\
\hline Law & .8098875 & .0388817 & -4.39 & 0.000 & .7371562 & .8897947 \\
\hline Science & .864289 & .0403067 & -3.13 & 0.002 & .7887923 & .9470117 \\
\hline Agriculture & 1.029628 & .109263 & 0.28 & 0.783 & .8362805 & 1.267678 \\
\hline Medicine & .8942873 & .1072999 & -0.93 & 0.352 & .7068817 & 1.131377 \\
\hline Business & 1.052941 & .0334222 & 1.63 & 0.104 & .9894307 & 1.120528 \\
\hline Manufacturing & 1.059334 & .2851694 & 0.21 & 0.830 & .6250172 & 1.795451 \\
\hline Engineering (omitted) & & & & & & 1.002697 \\
\hline Female Graduates & 1.051389 & .0254369 & 2.07 & 0.038 & & \\
\hline Male Graduates(omitted) & & & & & & \\
\hline
\end{tabular}

Table 8. Test of Proportionality for reputation of University

\begin{tabular}{|c|c|c|c|c|}
\hline$-{ }^{\mathrm{t}}$ & Coefficient & Std. & Err. & $\mathrm{z}$ \\
\hline main & & & & \\
\hline High Reputation Four-year University & -.3393067 & .1940859 & -1.75 & 0.080 \\
\hline Ordinary Four-year College & .3068257 & .1951245 & 1.57 & 0.116 \\
\hline Tvc & & & & \\
\hline High Reputation Four-year University & .2635443 & .0980981 & 2.69 & 0.007 \\
\hline Ordinary Four-year College & -.0641247 & .0988364 & -0.65 & 0.516 \\
\hline
\end{tabular}

Variables in tvc equation interacted with unemployment spell. 
Table 9. Test of Proportionality for Major

\begin{tabular}{|c|c|c|c|c|}
\hline$-\mathrm{t}$ & Coefficient & Std. & Err. & $\mathrm{z}$ \\
\hline main & & & & \\
\hline Arts and Social Science & .5717838 & .1317307 & 4.34 & 0.000 \\
\hline Law & .6099617 & .1888803 & 3.23 & 0.001 \\
\hline Science & .4797013 & .1903226 & 2.52 & 0.012 \\
\hline Agriculture & .3707172 & .4399485 & 0.84 & 0.399 \\
\hline Medicine & .5129884 & .4831602 & 1.06 & 0.288 \\
\hline Business & .806235 & .1281031 & 6.29 & 0.000 \\
\hline Tvc & & & & \\
\hline Arts and Social Science & -.3219655 & .0674005 & -4.78 & 0.000 \\
\hline Law & -.4208531 & .0964596 & -4.36 & 0.000 \\
\hline Science & -.3321993 & .0970837 & -3.42 & 0.001 \\
\hline Agriculture & -.1777074 & .2267538 & -0.78 & 0.433 \\
\hline Medicine & -.3327603 & .2493381 & -1.33 & 0.182 \\
\hline Business & -.3961525 & .0660179 & -6.00 & 0.000 \\
\hline
\end{tabular}

Variables in tvc equation interacted with unemployment spell.

Table 10. Test of Proportionality for Gender

\begin{tabular}{|c|c|c|c|c|}
\hline$-{ }^{\mathrm{t}}$ & Coefficient & Std. & Err. & $\mathrm{z}$ \\
\hline main & & & & \\
\hline Female Graduate & .3252333 & .0927555 & 3.51 & 0.000 \\
\hline Tvc & & & & \\
\hline Female Graduate & -.1475577 & .0477292 & -3.09 & 0.002 \\
\hline
\end{tabular}

Variables in tvc equation interacted with unemployment spell.

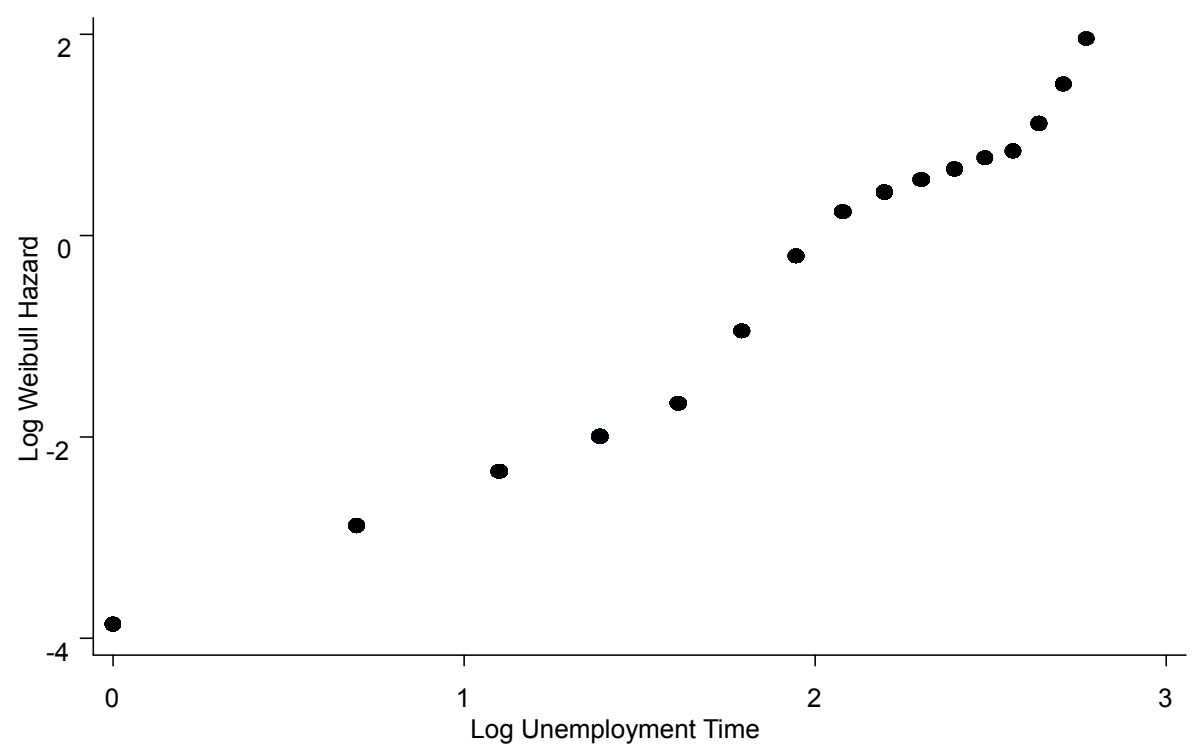

Figure 1. Trend of Log of the Weibull Hazard 


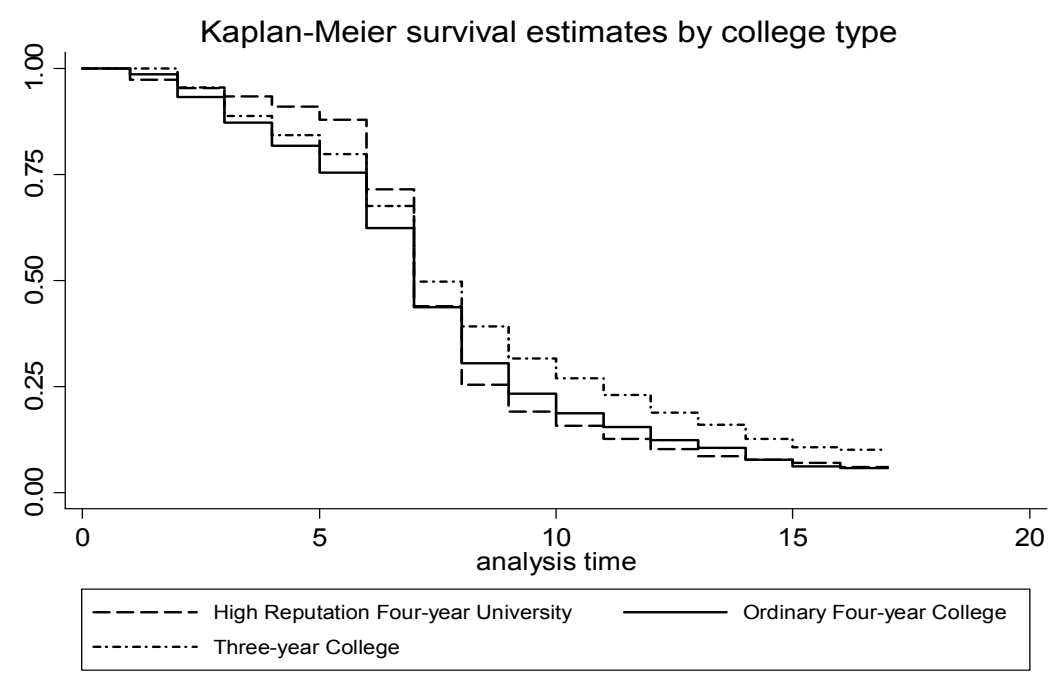

Figure 2. Kaplan-Meier Survival Estimates by College Type

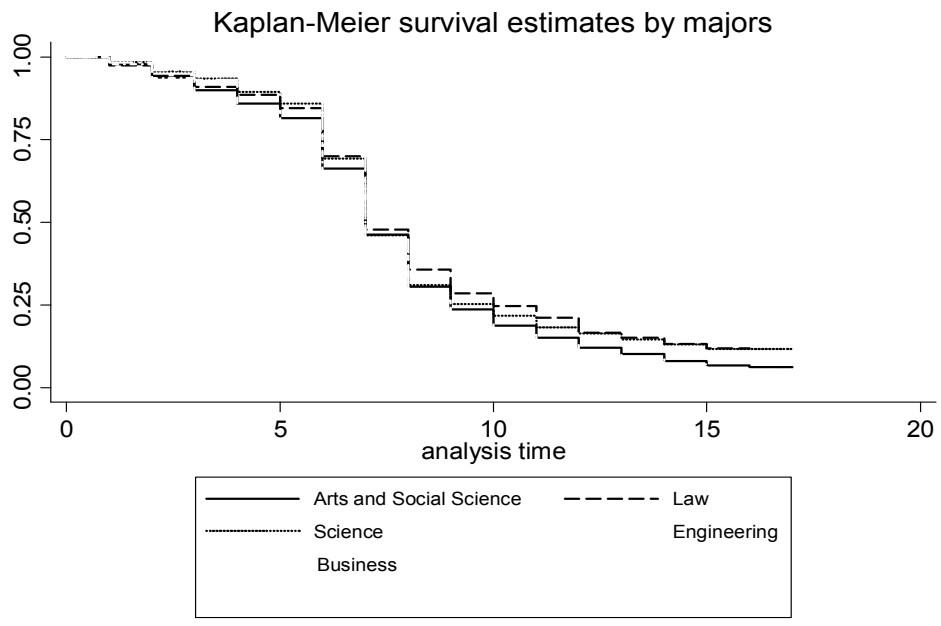

Figure 3. Kaplan-Meier Survival Estimates by Major

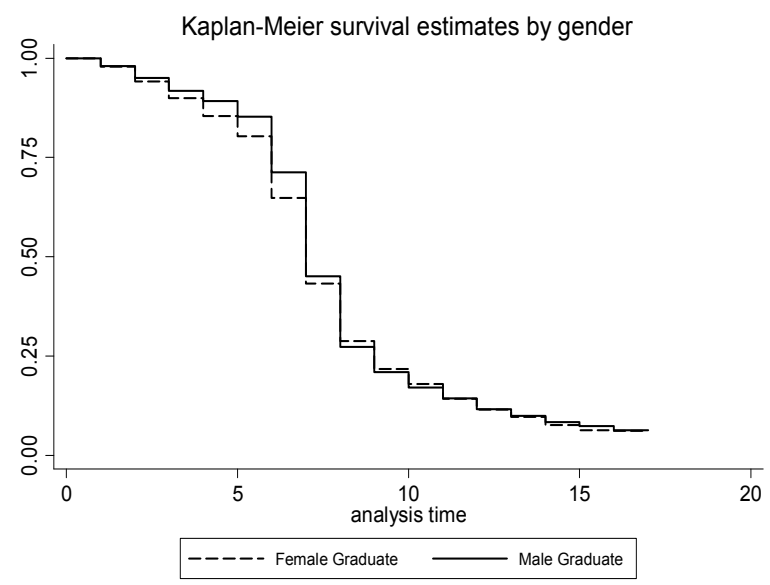

Figure 4. Kaplan-Meier Survival Estimates by Gender 